\title{
MODIFIKASI PISAU DAN POROS ALAT PENEPUNG IKAN UNTUK PENINGKATKAN KAPASITAS PRODUKSI TEPUNG IKAN
}

\section{MODIFICATION THE BLADES AND SHAFT OF HAMMER MILL FOR \\ INCREASE FISH MEAL PRODUCTION CAPASITY}

\author{
Sulharman \\ Baristand Industri Samarinda, \\ JI.Harmonika No. 3, Samarinda Telp. 0541-732274, Fax.0541-745431 \\ Email : sulharman@kemenperin.go.id
}

Naskah diterima 14 Maret 2011, disetujui 8 Juni 2011

\begin{abstract}
ABSTRAK
Telah dilakukan modifikasi pisau dan poros alat penepung ikan untuk peningkatan kapasitas produksi tepung ikan. Tujuannya adalah sebagai upaya meningkatkan momen torsi alat sehingga dapat menghasilkan waktu yang lebih efisien dan jumlah produksi tepung ikan yang lebih banyak. Modifikasi dilakukan dengan penambahan flywheel pada poros alat penepung, yang meliputi beberapa pengujian, yaitu (1) variasi putaran mesin,(2) jumlah mata pisau,(3) bentuk sudut pisau $135^{\circ}$. Berdasarkan hasil sampel sebanyak tiga kali pengulangan, didapat kapasitas tepung ikan sebagai berikut:(1)Naik sebesar 78\% pada putaran 1750 rpm, jumlah pisau 27 buah dan bentuk sudut pisau $135^{\circ}$,(2) turun sebesar $68 \%$ pada putaran $1750 \mathrm{rpm}$, jumlah pisau 18 buah dan bentuk pisau lurus,(3) turun sebesar 56,6\% pada putaran 1750 rpm, jumlah pisau 18 buah dan bentuk pisau lurus. Hasil sebelum dan sesudah alat dimodifikasi didapat perbedaan kapasitas sebesar 7,8 kali $(118 \mathrm{~kg} / 15 \mathrm{~kg})$ atau ada kenaikkan $686 \%$ (118kg-15kg/15kgx100\%). Analisa tekno ekonomi didapat nilai BEP sebesar Rp. $326.403 \mathrm{~kg}$ per tahun, presentase BEP adalah 32,38\%, kapasitas pada BEP adalah $77.712 \mathrm{~kg}$ per tahun dan waktu kembali modal adalah 2 tahun 3 bulan.
\end{abstract}

Kata kunci : alat penepung ikan, flywheel, modifikasi, pisau.

\begin{abstract}
They modified the blades and shaft of hammer mill for increase fish meal production capacity. The purpose is an effort to increase the moment of torque tools that can generate a more efficient time and amount of production of fish meal. Modifications performed by the addition of the flywheel on the shaft hammer mill, which includes several tests, namely (1) variations in engine speed, (2) the number of blades, (3) makes an angle of blade $135^{\circ}$. Base on three times repetition of the sample results, obtained by the capacity of fish meal as follows: (1) Increase by $78 \%$ at $1750 \mathrm{rpm}$ rotation, the number of blades 27 pieces and shape of the blade angle $135^{\circ}$, (2) decreased by $68 \%$ at $1750 \mathrm{rpm}$ rotation, the number of blades 18 pieces and form a straight blade, (3) decreased amounting to $56.6 \%$ at $1750 \mathrm{rpm}$ rotation, the number of blades 18 pieces and form a straight blade. The results before and after the modified instrument obtained a difference 7.8 times the capacity $(118 \mathrm{~kg} / 15 \mathrm{~kg})$ or increase of $686 \%(118 \mathrm{~kg}-15 \mathrm{~kg} / 15 \mathrm{~kg} \times 100 \%)$. Techno economic analysis BEP values obtained for $R$ p. $326,403 \mathrm{~kg}$ per year, the percentage was $32.38 \%$ BEP, BEP capacity of $77,712 \mathrm{~kg}$ per year and the payback period is 2 years and 3 months.
\end{abstract}

Keywords : blade, flywheel, hammer mills of fish meal, modification. 


\section{PENDAHULUAN}

$\mathrm{K}$ alimantan Timur tidak hanya memiliki lahan darat yang luas dan potensial tapi juga mempunyai potensi perikanan dan kelautan yang sangat prospektif terdiri dari wilayah ZEEI (Zone Ekonomi Ekslusif Indonesia) sepanjang Laut Sulawesi seluas 2.750 .813 ha, wilayah penangkapan di pantai seluas 12 juta ha, perairan umum seluas 2,77 juta ha. Untuk potensi produksi sumberdaya ikan di Kalimantan Timur terdiri dari perairan laut : 139.200 ton dimanfaatkan sekitar 40,94\%, perairan umum : 69.348 ton dimanfaatkan sekitar 20,40\%, budidaya tambak : 122.450 ton yang dimanfaatkan sekitar $36,02 \%$ dan budidaya air tawar : 9.000 ton yang dimanfaatkan sekitar $2,64 \%$. ( www.kaltimprov.go.id).

Hasil tangkapan ikan yang tidak bernilai ekonomis selama ini hanya dibuang ke laut. Bila dimanfaatkan dapat memberikan nilai tambah.

Produk olahan tepung ikan merupakan salah satu bahan baku untuk pakan ikan dan pakan ternak yang mengandung protein tinggi. Tepung ikan digunakan dalam formulasi pakan dengan tingkat pemakaian berkisar $15 \%$ pada pakan ikan/ udang dan $5 \%$ pada pakan unggas. Produk tepung ikan tersebut dapat dibuat dari ikan hasil tangkapan berlebihan atau ikan - ikan yang mempunyai nilai ekonomis rendah hasil tangkapan sampingan nelayan, seperti ikan tembang, ikan peperek, ikan pitek dan lain - lain.

Ironisnya Indonesia sebagai negara bahari masih $70 \%$ mengimpor bahan baku.

Dibutuhkan $0,25-0,75$ juta ton tepung ikan setiap tahunnya. Dari kebutuhan tersebut, $70 \%$ masih harus diimpor dari berbagai negara seperti Peru dan Chili. Impor tepung ikan Indonesia tahun 2000 menurut data BPS adalah
87.275 ton dengan nilai US\$ 39,483 juta.(www.agritekno.tripod.com/tepung_ ikan.htm).

Alat penepung ikan yang ada dipengusaha keramba ikan di Loa Kulu Kab. Kutai Kertanegara dirasakan tidak efisien, seperti jumlah yang dihasilkan masih kecil (11 - $15 \mathrm{~kg} / \mathrm{jam})$ (Personal Communication, 2005). Apabila kapasitas (ikan kering ditambahkan) pada alat penepung ikan tersebut, maka alat tersebut akan berhenti karena banyaknya volume ikan yang masuk sementara ikan yang sudah ada di dalam alat belum semuanya menjadi tepung.

Penelitian ini bertujuan memodifikasi pisau dan poros alat penepung ikan dengan menambahkan flywheel sehingga dapat meningkatkan momen torsi alat. Dengan adanya modifikasi tersebut diharapkan dapat menghasilkan waktu yang lebih efisien dan jumlah produksi tepung ikan yang lebih banyak.

\section{Landasan Teori}

Kecepatan Potong

Kecepatan potong (V) ialah jarak yang ditempuh titik terluar pisau (mata pisau) dalam satuan meter per detik. Kecepatan potong tergantung pada jumlah putaran poros alat (n) dan garis tengah lingkaran (d) (Sutedja Wiraatmadja, 2002).

Kecepatan potong dapat dihitung berdasarkan :

$\mathrm{V}=\mathrm{d} \cdot \pi \cdot \mathrm{n}$

\section{0}

Dimana :
$\mathrm{n}=$ kecepatan putaran per menit (putaran / menit)
$\mathrm{d}=$ diameter alat $(\mathrm{mm})$
$\mathrm{V}=$ kecepatan potong ( $\mathrm{m} /$ detik) Sementara gaya sentrifugal diberikan oleh :
$\mathrm{F}_{\mathrm{sf}}=\frac{\mathrm{m} \cdot \mathrm{V}^{2}}{\mathrm{r}}$

(Soemadi, Nazwir, 1978) 
Dimana :

$$
\begin{aligned}
\mathrm{F}_{\mathrm{sf}} & =\text { gaya sentrifugal }(\mathrm{N}) \\
\mathrm{m} & =\text { masa yang berputar }(\mathrm{kg}) \\
\mathrm{V} & =\text { kecepatan keliling }(\mathrm{m} / \text { detik }) \\
\mathrm{r} & =\text { radius }(\mathrm{m})
\end{aligned}
$$

Momen torsi (putar) atau momen puntir adalah gaya yang ditimbulkan oleh gerak putar.

$\mathrm{T}=$ Momen torsi yaitu rxF $(\mathrm{kgm})$

Dimana :

$\mathrm{F}=$ gaya keliling yang menyebabkan poros berputar $(\mathrm{N})$

$r=$ jari - jari poros $(\mathrm{m})$

Sedangkan daya penggerak diberikan oleh :

$\mathrm{P}=\mathrm{T} \cdot \mathrm{n} \quad(\mathrm{hp})$

$$
63.000
$$

Dimana :

$$
\begin{aligned}
& \mathrm{P}=\text { daya (watt) } \\
& \mathrm{T}=\text { torsi as (lb.in) } \\
& \mathrm{n}=\text { kecepatan putaran per menit } \\
& \quad \text { (putaran / menit) } \\
& \quad \begin{array}{l}
\text { Untuk mencari putaran mesin } \\
\text { penggerak menggunakan } \\
\text { perbandingan transmisi diberikan oleh : }
\end{array}
\end{aligned}
$$

$$
d_{1} \cdot n_{1}=d_{2} \cdot n_{2}
$$

Dimana :

$$
\begin{aligned}
& \mathrm{d}_{1} \quad=\text { diameter pully mesin } \\
& \text { penggesak }(\mathrm{m}) \\
& \mathrm{d}_{2} \quad=\text { diameter pully penepung }(\mathrm{m}) \\
& \mathrm{n}_{1} \quad=\text { putaran per menit mesin } \\
& \text { penggerak (putaran / menit) } \\
& \mathrm{n}_{2} \quad=\text { putaran per menit penepung } \\
& \text { (putaran / menit) }
\end{aligned}
$$

Bahan - bahan yang digunakan yaitu ikan kering, karung, kemasan plastik, besi siku, as, flywheel, plat besi, roda, plat stainless steel, baut, mur, selang, elektroda las, oksigen, elpiji, mesin penggerak serta peralatan yang digunakan adalah tachometer, stopwatch, tabung ukur, mesin las, mesin potong, mesin bubut, gerinda, timbangan, masker dan sarung tangan.

Adapun tahapan penelitian sebagai berikut :

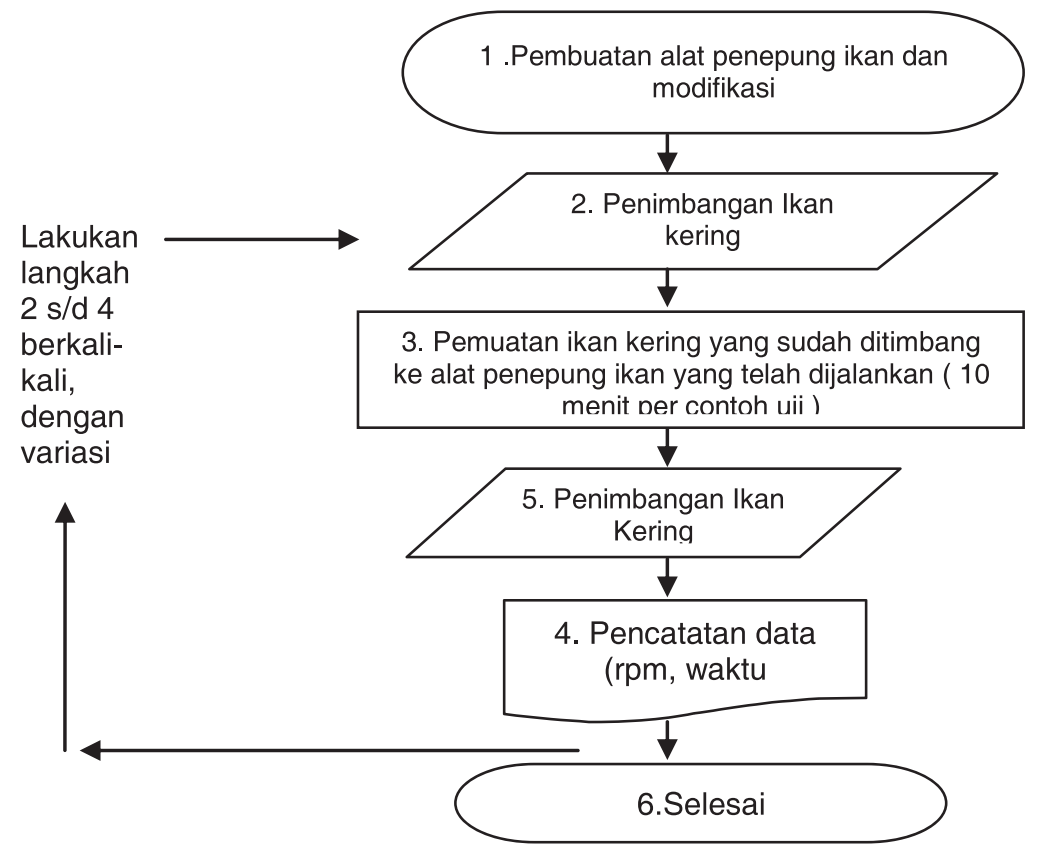

Gambar.1 Tahapan proses pengujian alat tepung ikan

Setelah desain dan pembuatan alat dilakukan maka dilakukan pengujian pendahuluan yang bertujuan untuk menguji kerja alat secara keseluruhan sebelum melakukan perhitungan sesungguhnya. Prinsip 
kerja alat penepung ikan yaitu menghidupkan mesin penggerak kemudian memasukkan ikan pada tempat pemasukan ikan kemudian menampung tepung ikan pada bagian bawah cyclone dengan karung.

Pengujian alat yang telah jadi tersebut diuji dengan variasi putaran mesin (1000 rpm, $1400 \mathrm{rpm}, 1750$ rpm), jumlah mata pisau (18 buah dan 27 buah) dan bentuk pisau (lurus dan bersudut $135^{\circ}$ ). Dari tiap - tiap putaran mesin dicatat kapasitas tepung ikan yang dihasilkan per satuan waktu. Masing-masing variasi rpm, jumlah pisau dan bentuk pisau diambil sampel sebanyak 3 (tiga) kali pengulangan.

Kapasitas pada jumlah pisau 18 buah dengan putaran $1750 \mathrm{rpm}$ meningkat sebesar $69,8 \% \quad(1,39 \mathrm{~kg} / 2$ $\mathrm{kg} \times 100 \%$ ), pada putaran $1400 \mathrm{rpm}$ $53,8 \%(1,07 \mathrm{~kg} / 2 \mathrm{~kg} \times 100 \%)$ dan pada putaran $1000 \mathrm{rpm}$ hanya $16,5 \%(0,33$ $\mathrm{kg} / 2 \mathrm{~kg} \times 100 \%)$. Sedangkan kapasitas pada jumlah pisau 27 buah dengan putaran $1750 \mathrm{rpm}$ meningkat sebesar $78 \% \quad(1,56 \mathrm{~kg} / 2 \mathrm{~kg} \times 100 \%)$ pada putaran $1400 \mathrm{rpm} 54,8 \%(1,09 \mathrm{~kg} / 2 \mathrm{~kg}$ x $100 \%$ ) dan pada putaran $1000 \mathrm{rpm}$ hanya $17,3 \%(0,34 \mathrm{~kg} / 2 \mathrm{~kg} \times 100 \%)$. Hal ini membuktikan bahwa dengan naiknya putaran alat dan bertambahnya jumlah pisau akan meningkatkan kapasitas karena kecepatan potong berbanding lurus dengan putaran alat (rumus 1).

Kapasitas pada jumlah pisau 18 buah dengan putaran $1750 \mathrm{rpm}$ meningkat sebesar $69,8 \% \quad(1,39 \mathrm{~kg} / 2$ $\mathrm{kg} \times 100 \%$ ), pada putaran $1400 \mathrm{rpm}$ $53,8 \%(1,07 \mathrm{~kg} / 2 \mathrm{~kg} \times 100 \%)$ dan pada putaran $1000 \mathrm{rpm}$ hanya $16,5 \%(0,33$ $\mathrm{kg} / 2$ kg x 100\%). Sedangkan kapasitas pada jumlah pisau 27 buah dengan putaran $1750 \mathrm{rpm}$ meningkat sebesar $78 \% \quad(1,56 \mathrm{~kg} / 2 \mathrm{~kg} \times 100 \%)$ pada putaran $1400 \mathrm{rpm} 54,8 \%(1,09 \mathrm{~kg} / 2 \mathrm{~kg}$ x $100 \%$ ) dan pada putaran $1000 \mathrm{rpm}$ hanya $17,3 \%(0,34 \mathrm{~kg} / 2 \mathrm{~kg} \times 100 \%)$. Hal ini membuktikan bahwa dengan naiknya putaran alat dan bertambahnya jumlah pisau akan meningkatkan kapasitas karena kecepatan potong berbanding lurus dengan putaran alat (rumus 1).

Perubahan sudut pisau dari lurus menjadi $135^{\circ}$ akan meningkatkan kapasitas hal ini disebabkan ada pertambahan panjang sehingga berat pisau bertambah, sehingga gaya sentrifugal bertambah. Massa (berat) berbanding lurus dengan gaya sentifugal (rumus 2).

Pada Gambar 4a ditampilkan alat yang belum dimodifikasi tanpa flywheel pada porosnya selanjutnya pada Gambar 4b ditampilkan alat yang sudah dimodifikasi dengan penambahan flywheel pada porosnya.

Penambahan flywheel dengan diameter $43 \mathrm{~cm}$, dan berat $50 \mathrm{~kg}$ pada Gambar 4b dimaksudkan untuk memperbesar momen torsi pada poros penepung, sehingga daya yang dihasilkan menjadi lebih besar dan putaran poros dapat konstan saat beban berlebihan.

Diamater poros alat penepung ikan yang belum dimodifikasi adalah 4 $\mathrm{cm}$, dengan berat $5,1 \mathrm{~kg}$. Dengan menggunakan rumus 3 didapat momen torsi yang terjadi 0,103 kgm, sedangkan pada alat yang menggunakan flywheel momen torsi yang terjadi adalah 10,75 kgm.

Dari sini dapat diketahui perbedaan momen torsi yang terjadi sebesar 104 kali. Dengan torsi sebesar $10,75 \mathrm{kgm}$ pada poros yang memakai flywheel tidak akan menyebabkan alat berhenti saat beban berlebihan.

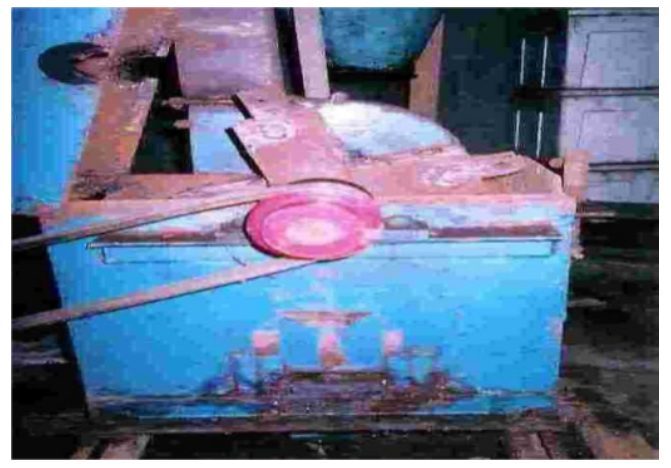


Gambar 4a. Alat penepung yang belum dimodifikasi pada porosnya (tanpa flywheel)

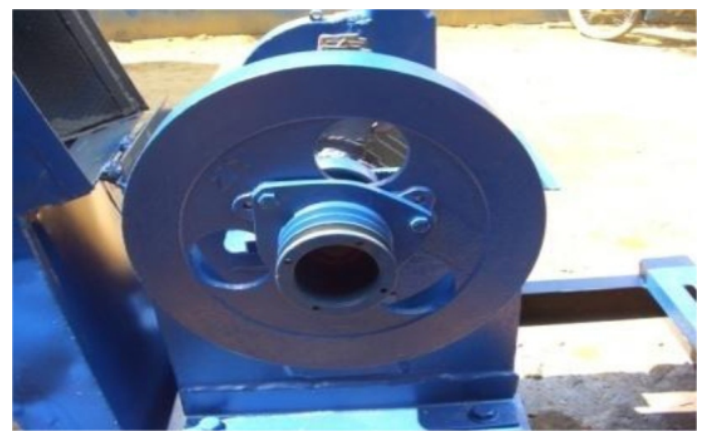

Gambar 4b. Alat penepung yang sudah dimodifikasi pada porosnya (menggunakan flywheel)

Selanjutnya pada Gambar 5a ditampilkan alat yang belum dimodifikasi bentuk pisau lurus selanjutnya pada Gambar 4b ditampilkan alat yang sudah dimodifikasi dengan bentuk sudut pisau $135^{\circ}$

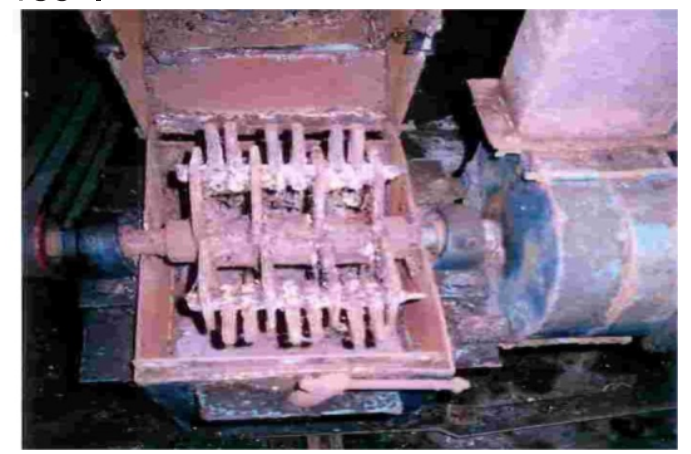

Gambar 5a. Alat penepung yang belum dimodifikasi ( bentuk pisau lurus )

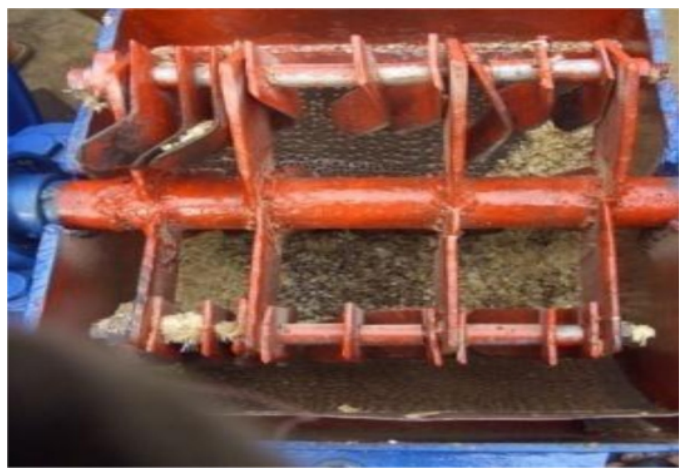

Gambar 5b. Alat sudah modifikasi ( bentuk sudut pisau $135^{\circ}$ )

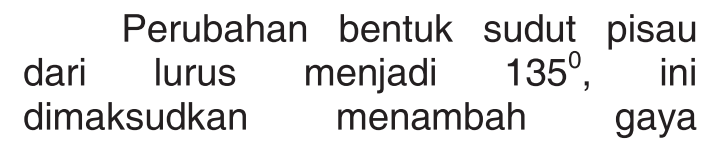

sentrifugal dan memperpanjang sisi potong. Dengan perubahan sudut menjadi $135^{\circ}$ ada penambahan panjang pisau (sisi potong) sebesar 1,5 $\mathrm{cm}$ dan peningkatan massa pisau sehingga kapasitas pun meningkat. Sudut pisau tidak dapat dibuat lebih dari $135^{\circ}$ karena akan mengenai sisi bak dalam alat penepung ikan, baik pada putaran rendah maupun tinggi.

Untuk pisau modifikasi memiliki sudut $135^{\circ}$ panjang $10,5 \mathrm{~cm}$, lebar 5 $\mathrm{cm}$, tebal $5 \mathrm{~mm}$, berat $150 \mathrm{gr}$. Sedangkan pisau lurus yang belum dimodifikasi memiliki panjang $9 \mathrm{~cm}$, lebar $5 \mathrm{~cm}$, tebal $5 \mathrm{~mm}$ dan berat 120 g.

Dengan menggunakan rumus 1 didapat kecepatan potong alat pemotong ikan (belum dimodifikasi) sebesar 10,07 m/det. Sedangkan gaya sentrifugal yang terjadi didapat dari rumus 2 sebesar 11,062 Newton. Untuk kecepatan potong alat penepung ikan hasil modifikasi didapat $11,45 \mathrm{~m} /$ det dan gaya sentrifugal yang terjadi adalah 15,73 Newton.

Dari hasil uji, kapasitas terbesar yang dihasilkan yaitu $1,56 \mathrm{~kg}$ (rata-rata) diperoleh dari jumlah pisau 27 dengan bentuk pisau $135^{\circ}$ pada putaran 1750 rpm. Sedangkan pada jumlah pisau 27 dengan bentuk pisau lurus pada putaran $1750 \mathrm{rpm}$ didapat kapasitas $1,36 \mathrm{~kg}$ (rata-rata). Ada selisih sebesar $0,2 \mathrm{~kg}$. Hal ini menujukkan bahwa dengan meningkatnya putaran alat penepung akan meningkatkan kapasitas. Hal ini membuktikan bahwa dengan naiknya putaran alat akan meningkatkan kapasitas karena kecepatan potong berbanding lurus dengan putaran alat (rumus 1).

Kapasitas aktual suatu alat adalah kemampuan alat tersebut untuk menghasilkan suatu produk per satuan waktu aktual. Kapasitas dihitung pada putaran $1750 \mathrm{rpm}$ dengan jumlah pisau 27 buah dengan bentuk sudut pisau $135^{\circ}$ didapat $118,04 \mathrm{~kg} / \mathrm{jam}$ dengan rendemen sebesar $78,37 \%$.

Daya penggerak minimum dihitung dengan persamaan (rumus 4). 


$$
\begin{aligned}
& P=\frac{T \cdot n}{63 \cdot 000} \\
& \frac{8,8548 \mathrm{lb} \cdot \mathrm{in} \times 1000 \mathrm{rpm}}{63.000}=0,1405 \mathrm{hp} \\
& =104,8 \text { watt }
\end{aligned}
$$

Sedangkan putaran mesin penggerak ke as penepung dihitung dengan persamaan ( rumus 5 ). $d_{1} \cdot n_{1}=$ $\mathrm{d}_{2} \cdot \mathrm{n}_{2}$, untuk putaran $1000 \mathrm{rpm}\left(\mathrm{n}_{2}\right)$ as penepung, maka putaran mesin penggerak $\left(n_{1}\right)$ :

$$
\begin{aligned}
& \mathrm{n}_{1}=\frac{1000 \mathrm{rpm}}{0,11 \mathrm{~m} / 0,14 \mathrm{~m}}=1.272 \mathrm{rpm} \\
& \mathrm{n}_{1}=\frac{1400 \mathrm{rpm}}{0,11 \mathrm{~m} / 0,14 \mathrm{~m}}=1.781 \mathrm{rpm} \\
& \mathrm{n}_{1}=\frac{1750 \mathrm{rpm}}{0,11 \mathrm{~m} / 0,14 \mathrm{~m}}=2.227 \mathrm{rpm}
\end{aligned}
$$

\section{ANALISA TEKNO EKONOMI}

Analisa tekno ekonomi didapat nilai BEP sebesar Rp. $326.403 \mathrm{~kg}$ per tahun, presentase BEP adalah 32,38 $\%$, kapasitas pada BEP adalah 77.712 $\mathrm{kg}$ per tahun dan waktu kembali modal adalah 2 tahun 3 bulan.

\section{KESIMPULAN DAN SARAN}

Kapasitas tepung ikan terbanyak pada putaran $1750 \mathrm{rpm}$ dengan jumlah pisau 27 buah dan bentuk sudut pisau $135^{\circ}$ meningkat sebesar $78 \%$. Pada jumlah pisau 27 buah dengan bentuk pisau lurus kapasitas yang dihasilkan $68 \%$, pada jumlah pisau 18 buah dengan bentuk lurus kapasitas yang dihasilkan hanya $56,6 \%$ sedangkan pada jumlah pisau 18 buah dengan bentuk sudut pisau $135^{\circ}$ kapasitas naik menjadi $69,8 \%$. Kapasitas aktual alat $118,04 \mathrm{~kg} / \mathrm{jam}$ dengan rendemen sebesar $78,37 \%$. Pada tiap-tiap putaran mesin dengan beban yang bervariasi tidak menyebabkan mesin berhenti, karena adanya penambahan flywheel pada poros penepung ikan. Perbedaan kapasitas alat sebelum dan sesudah dimodifikasi sebesar 7,8 kali $(118 \mathrm{~kg} /$ $15 \mathrm{~kg})$ atau ada kenaikkan $686 \%$ (118kg-15kg/15kg x 100\%). Analisa tekno ekonomi didapat nilai BEP sebesar Rp. $326.403 \mathrm{~kg}$ per tahun, presentase BEP adalah 32,38 \%, kapasitas pada BEP adalah $77.712 \mathrm{~kg}$ per tahun dan waktu kembali modal adalah 2 tahun 3 bulan. Dengan telah disosialisasikan nya alat penepung ikan ini di daerah Kaltim dan telah beberapa kali diuji cobakan di pabrik pakan maka alat ini sangat berhasil mengatasi permasalahan yang ada, oleh karenanya alat penepung ikan ini layak mendapatkan paten.

\section{DAFTAR PUSTAKA}

Mott, Robert L, 2004. Elemen-Elemen Mesin dalam Perancangan Mekanis. Penerbit Andi. Yogyakarta

Soemadi, Nazwir, 1978. Mekanika Teknik 1. Departemen Pendidikan dan Kebudayaan. Jakarta

Stolk,Jack dan Kros, C, 1981. Elemen Mesin. Erlangga. Jakarta

Suarga, 2006. Algoritma Pemrograman. PenerbitAndi Ilmu. Yogyakarta

Sutanta Edhy, 2004. Algoritma Teknik Penyelesaian Permasalahan Untuk Komputasi. Graha Ilmu.Yogyakarta.

Sutedja Wiraatmadja, 2002. Pengiris Dan Pemotong. Penebar Swadaya. Jakarta.

Tosin Rijanto, 1994. Flow Chart untuk Siswa dan Mahasiswa. Dinastindo. Jakarta.

http: // www.kaltimprov.go.id/potensi daerah, diakses 9 Oktober 2011.

http:// www.agritekno.tripod.com/ tepung_ikan.htm, diakses 3 Mei 2011. 